\title{
Gaur egungo hidrogeno-ekoizpena: metanoaren ur-lurrun bidezko erreformatzea
}

\author{
(Current hydrogen production: methane steam reforming)
}

\author{
Ane Gondra ${ }^{1}$, Maialen Araneta ${ }^{2}$, Jose Miguel Campillo-Robles*1 \\ ${ }^{1}$ Zientzia eta Teknologia Fakultatea, Euskal Herriko Unibertsitatea (UPV/EHU) \\ ${ }^{2}$ Industria Diseinuko ikertzailea
}

LABURPENA: Gure gizartean, gero eta garrantzi handiagoa duen energia-iturria da hidrogenoa. Ekoizpen-teknika guztien artean, metanoaren ur-lurrun bidezko erreformatzea da erabiliena. Prozesua honako urrats hauetan oinarritzen da: gas naturalaren garbiketa, beroketa-prozesua, labe erreformatzailea, ur-lurrunaren bihurketa eta hidrogenoaren bereizketa; horien artean, labe erreformatzailea da elementurik garrantzitsuena. Dena den, teknika honek hainbat erronka ditu, isuritako $\mathrm{CO}_{2}$-ari, katalizatzaileen diseinuari eta energia-kontsumoari lotutakoak. Dokumentu honetan, metanoaren lurrun-bidezko erreformatze-prozesuaren deskribapen orokorra aurkezten da, errekuntza-ganberaren, katalizatzaileen, eraginkortasun termikoaren eta labe erreformatzailearen modelizazioaren nondik norakoak azalduz.

HITZ GAKOAK: hidrogeno-ekoizpena, ur-lurrunaren bidezko erreformatzea, metanoa, labea, eraginkortasun termikoa, modelizazioa.

ABSTRACT: In our society, hydrogen is an increasingly important source of energy. Among all the production techniques, methane steam reforming is the most widely used. This process is based on the following steps: natural gas cleaning, heating process, reforming furnace, water-steam conversion and hydrogen separation; the most significant being the reforming furnace. However, this technique has several challenges related to the emitted $\mathrm{CO}_{2}$, the design of the catalysts and the energy consumption. This paper presents a general description of the methane steam reforming process, providing an overview of the combustion chamber, catalysts, thermal efficiency and modelling of the reforming furnace.

KEYWORDS: hydrogen production, steam reforming, methane, furnace, thermal efficiency, modelling.

\footnotetext{
* Harremanetan jartzeko / Corresponding author: Jose Miguel Campillo-Robles. Fisika Saila, Zientzia eta Teknologia Fakultatea (UPV/EHU), 48940 Leioa. - joxemi.campillo@ehu.eus - https://orcid.org/0000-0002-2565-6343

Nola aipatu / How to cite: Gondra, Ane; Araneta, Maialen; Campillo-Robles, Jose Miguel (2021). «Gaur egungo hidrogeno-ekoizpena: metanoaren ur-lurrun bidezko erreformatzean. Ekaia, 41, 2021, 253-273. (https://doi.org/10.1387/ekaia.22379).

Jasotze-data: 2021, urtarrilak 2; Onartze-data: 2021, apirilak 19.

ISSN 0214-9753 - eISSN 2444-3581 / (c) 2021 UPV/EHU
}

c) (i) $\Theta$ Lan hau Creative Commons Aitortu-EzKomertziala-LanEratorririkGabe 4.0 Nazioartekoa

lizentzia baten mende dago 


\section{SARRERA}

Hidrogenoaren eskaera gero eta handiagoa da mundu osoan. Hurrengo hamarkadetan, hidrogeno-eskaera urtero \% 5-10 inguru hastea espero da [1]. Etorkizun handiko energia-iturritzat hartzen da hidrogenoa, eta erregai fosilak ordezka ditzake gaur egungo aplikazio gehienetan [2]. Petrolio-industria aspalditik jabetu da egoera honetaz, eta paradigma-aldaketarako prestatzen hasia da jadanik. Adibidez, Petronorrek eta Repsolek energia berriztagarrien bidez lortutako hidrogenoa erabili nahi dute erregaiak ekoizteko. Horretarako, munduko instalaziorik handienetako bat Bilboko portuan eraikitzeko asmoa azaldu zuten 2020ko ekainean [3].

Hidrogenoak abantaila ugari ditu [4]: hondakin kutsakorrik gabeko errekuntza, energia-dentsitate grabimetriko altua eta aplikazio-eremu zabala (industria kimikoa, petrolio-industria, energia-biltegiratzea, elektronika, metalurgia eta abar). Gaur egun, hidrogenoa nagusiki petrolio-findegietan eta produktu kimikoen ekoizpenean erabiltzen da, eta, maila apalagoan, baita energia-arloan ere. Egia esateko, hidrogenoa lehengai garrantzitsuenetakoa da petrolio-industrian, hidrotratatzeko eta hidrokrakeatzeko [5]. Adibidez, petrolio gordina balio handiko produktu ugari bihurtzeko erabiltzen da hidrogenoa (hala nola, gasolina, hegazkin-erregaia eta gasolioa), baina oso garrantzitsua da amoniakoa, metanola eta sintesi-gasak ekoizteko ere. Bestalde, hidrogenoan oinarritutako ekonomiaren paradigma berriaren garapena, batez ere, erregai-pilen erabilerarekin lotuta dagoela dirudi [6].

Urteko hidrogeno-ekoizpena munduan 70 milioi tona ingurukoa da, eta ekoitzitako hidrogenoaren \% 90-95 inguru metanoaren ur-lurrun bidezko erreformatzetik lortzen da [7, 8]. Artikulu honetan, teknologia horren ezaugarri garrantzitsuenak deskribatuko ditugu, ohiko problematikak eta erronka nagusiak aipatuz.

\section{HIDROGENOAREN EKOIZPENA}

1. irudian, hidrogenoa ekoizteko erabiltzen diren teknologia garrantzitsuenak, energia-iturriak eta lehengaiak ageri dira. Hidrogenoa hainbat modutan lortu daiteke; hala nola, prozesu termokimikoak, elektrokimikoak edota fotokimikoak erabilita. Horretarako, hidrokarburoak, ura, biomasa eta hondakinak erabiltzen dira lehengai modura. Ekoizpen-prozesuan, gas fasean erabiltzen dira gas naturala bezalako lehengaiak. Berriz, beste batzuk likido modura erabiltzen dira (ura, adibidez), edota hasieran solido direnak (ikatza, esaterako) gasifikatu egiten dira erabili aurretik. 
Gaur egungo hidrogeno-ekoizpena: metanoaren ur-lurrun bidezko erreformatzea

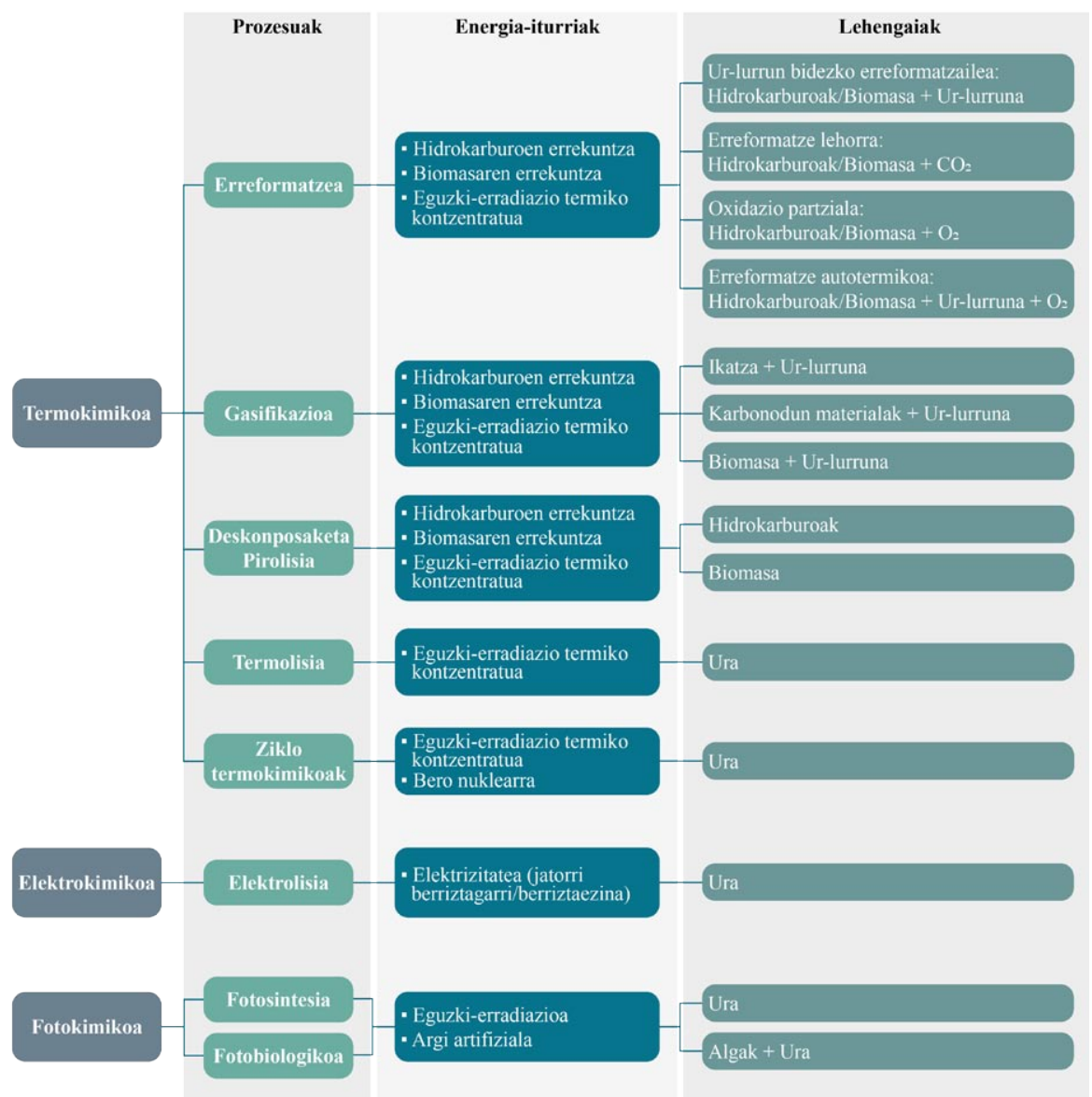

1. irudia. Hidrogenoa ekoizteko prozesuak, energia-iturriak eta lehengaiak $[9,10,11,12]$.

Hidrogenoa sortzeko metodo termokimiko asko daude (ikus 1. irudia), eta, horien artean, erreformatze katalitikoa da erabiliena. Metodo horretan, hidrogenoa lortzeko hidrokarburoak edo biomasa hainbat lehengairekin nahasten dira, urarekin (ur-lurrun bidezko erreformatzea), airearekin (oxidazio partziala), aurreko biekin (erreformatze autotermikoa) edota karbono dioxidoarekin (erreformatze lehorra). Gasifikazioa da beste metodo termokimiko bat. Teknologia horren bitartez, ikatzetik eta biomasatik lortzen da hidrogenoa, nahiz eta horietan dagoen hidrogeno kantitatea oso altua ez izan; masan, \% 2-5 eta \% 5-8 tartean, hurrenez hurren [13]. Azkenaldian, interes handia piztu du biomasatik, bereziki bio-oliotik, eratorritako hidrogenoak, izan dezakeen bideragarritasun ekonomikoa dela eta [14]. 
Uretatik abiatuz, hainbat metodo erabiltzen da hidrogenoa ekoizteko (ikus 1. irudia). Ziklo termokimikoen bidez hidrogenoa lortzen duten prozesuak ere badaude; adibidez, sulfuro-ioduro metodoa (S-I) eta sulfuroaren metodo hibridoa. Ura ere lehengaitzat hartzen da metodo elektrokimikoetan, elektrolisian esaterako. Azken horretan oinarritutako beste metodo bat ere badago, tenperatura altuko elektrolisia izenekoa, zeinetan tenperatura igoz prozesua eraginkorragoa eta elektrizitate-kostua txikiagoa baitira. Metodo horiez gain, aipatzekoak dira uraren deskonposaketa termikoa eta uraren banaketa fotokimikoak ere [13].

\section{METANOAREN UR-LURRUN BIDEZKO ERREFORMATZEA}

Metanoaren ur-lurrun bidezko erreformatzea ondo finkatutako teknologia heldua da [15]. 1913 urtean gauzatu ziren teknologia honekin loturiko lehenengo ikerketak eta garapen garrantzitsuak, BASFk nikel katalizatzailea patentatu zuenean [16]. Ondoren, 1930eko hamarkadan, AEBn martxan jarri ziren metanoaren ur-lurrun bidezko erreformatzea erabiltzen zuten lehenengo planta industrialak [17]. 1962an garapen teknologiko handiak izan ziren, ICIk nafta lehengai modura erabiltzen zuten presio altuko bi labe erreformatzaile tubular martxan jartzea lortu zuenean [18]. 1980an, erreformatzean sufre-pozoitzearekin izandako arazoak konpondu ziren aurre-erreformatzailearen erabilerari esker. Gainera, aurre-erreformatzailearen bidez, erreformatzaile tubularren sarrerako tenperatura altuagoa izatea eta horren tamaina txikiagoa izatea lortu zen (kostuak txikitu) [18]. Laurogeiko hamarkadan ere, erreformatze-prozesua oztopatzen duen koke-eraketaren inguruko ikerketa asko egin ziren, funtsezkoak izan direnak prozesuaren eraginkortasuna handitzeko.

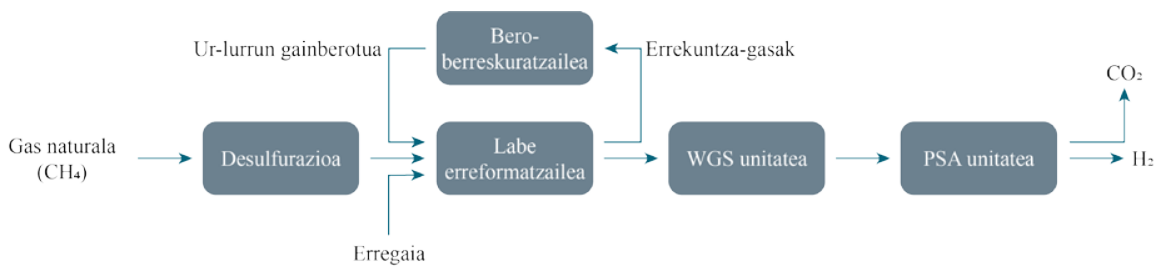

2. irudia. Metanoaren ur-lurrun bidezko erreformatze-prozesuaren fluxu-diagrama.

Metanoaren ur-lurrun bidezko erreformatzearen prozesu industriala hainbat urratsetan banatu ohi da (ikus 2. irudia) [19]:

- Gas naturalaren garbiketa. Hasieran, zink oxidoko pelletak erabiltzen dira gas naturalari sufredun konposatu organikoak eta kloroa kentzeko. Prozesu horri desulfurazio ere baderitzo. 
- Beroketa-prozesua. Erreformatze-prozesuaren lehengaiak, gas naturala eta ur-lurruna, tenperatura altuetan sartu behar dira labe erreformatzailean $\left(700-1.000{ }^{\circ} \mathrm{C}\right)$. Hori dela eta, labe erreformatzailearen konbekzio-dorreko bero-trukagailuetan berotzen dira tenperatura altuko errekuntza-gasen energia erabiliz.

- Labe erreformatzailea. Labe erreformatzailea da prozesuko elementurik garrantzitsuena, eta bi eskualdetan banatuta dago: erreaktorea eta errekuntza-ganbera. Bi eskualde horien artean ez dago masa-fluxurik, baina ez daude termikoki isolatuta, beren artean bero-fluxu handia gertatzen baita. Erreaktorea hainbat hoditan banatuta dago (ikus 3. irudia), eta, bertan, metanoaren ur-lurrun bidezko erreformatze katalitikoa gertatzen da. Metanoaren erreformatze-prozesua tenperatura eta presio altuetan $\left(700-1.000{ }^{\circ} \mathrm{C}, 3-25\right.$ bar) gertatzen da [7], katalizatzaileen presentzian. Horren ondorioz, sintesigasa lortzen da, nagusiki hidrogenoz, karbono dioxidoz eta karbono monoxidoz osatua dagoen nahasketa gaseosoa [20]. Errekuntza-ganberan gertatzen den konbustiotik lortzen da erreakzio katalitikoak behar duen energia.

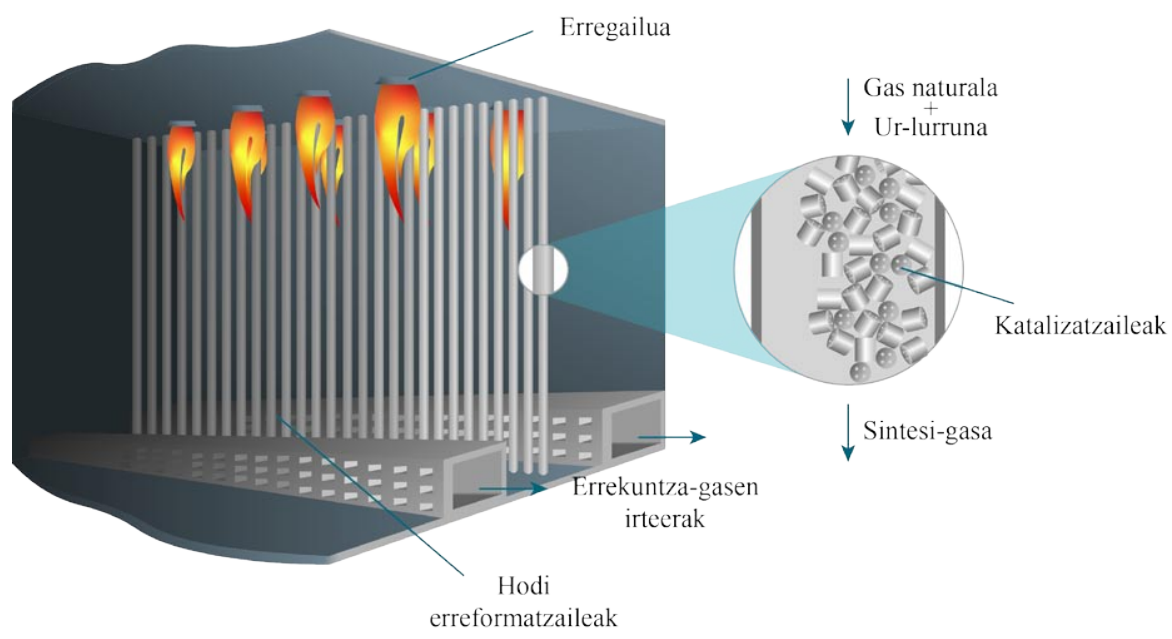

3. irudia. Goitik berotutako labe erreformatzailearen oinarrizko elementuak.

- Ur-lurrunaren bihurketa. Labe erreformatzailetik ateratzen den sintesi-gasean hidrogenoaren bihurketa-proportzioa areagotu daiteke. Horretarako, $\mathrm{H}_{2} / \mathrm{CO}$ proportzioaren gainean eragiten da ur-lurrunaren bihurketa (ingelesez, Water Gas Shift, WGS), erreakzioaren bitartez. Prozesu horretan, karbono monoxidoa eta ura erabiltzen dira hidrogenoa eta karbono dioxidoa lortzeko. Batzuetan, prozesu hori labe erreformatzailean bertan egiten da. Baina, gehienetan, ten- 
peratura baxuko erreaktore berezituan gertatzen da, labe erreformatzailearen ostean dagoena.

- Hidrogenoaren bereizketa. Labe erreformatzailetik edo WGS unitatetik ateratzen den sintesi-gasa tenperatura altuko erregai-pilak edo findegiko prozesu batzuk elikatzeko erabil daiteke zuzenean. Baina, tenperatura baxuko erregai-piletarako eta beste aplikazio batzuetarako (elikagai-industria, erdieroaleak, gas industrialak), purutasun handiko hidrogenoa behar da. Hori dela eta, behin hidrogenoaren proportzioa nahiko altua denean, sintesi-gasa bereizketa- eta arazketa-prozesuetatik pasarazten da. Hidrogenoa purifikatzeaz gain, prozesu horiek beste helburu gehigarri batzuk dituzte: erreakzionatu gabeko gasak birziklatzea $\left(\mathrm{CO}\right.$ eta $\left.\mathrm{CH}_{4}\right)$ eta berotegi-efektuko gasak, hala nola $\mathrm{CO}_{2}$ harrapatzea atmosferarako isurketak ekiditeko.

\subsection{Erreformatze katalitikoa}

Labe erreformatzailean dauden hodiak nikel-burdin-kromo aleazioz egin ohi dira, tenperatura altuetan isurpenarekiko erresistentzia handia dutelako [21]. Hodi horiek 100.000 h-ko lan-bizitza izateko diseinatuta daude [22], eta bakoitzak 15-30 mila dolarreko prezioa izan ohi du [23]. Zoritxarrez, oso sentikorrak dira lan-tenperaturaren aldaketekiko. Izatez, diseinu-tenperaturaren gainetik $20{ }^{\circ} \mathrm{C}$-ko tenperatura-gehikuntza luzaroan mantentzeak erdira murriztu dezake hodien lan-bizitza [24]. Hori dela eta, oso garrantzitsua da labearen barruko tenperatura-banaketa ondo kontrolatzea.
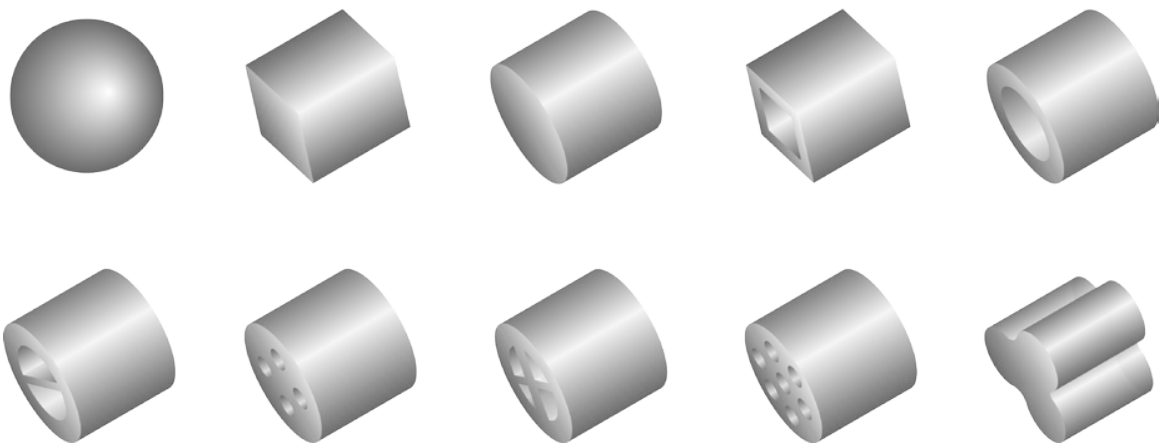

4. irudia. Metanoaren erreformatze katalitikoan erabiltzen diren katalizatzaileen hainbat pellet-forma $[25,26]$.

Metanoaren erreformatze-prozesuan, C-C eta $\mathrm{C}-\mathrm{H}$ loturak apurtzeko erabiltzen dira katalizatzaileak [26, 27, 28]. Oro har, lurrun bidezko erreformatzean baliatzen diren katalizatzaileek baldintza zorrotzak bete behar 
dituzte; esate baterako, aktibitate handia, bero-transmisio egokia, presiogalera baxua, erresistentzia mekaniko handia eta bizitza-denbora luzea. Industrian gehien erabiltzen diren katalizatzaileak nikelarekin dopatutakoak dira, merkeak eta oso selektiboak direlako. Katalizatzaile horiek aluminaz egindako pelleten gainazalean kokatzen dira (Ni/M-alumina, $\mathrm{M}=\mathrm{Mg}, \mathrm{Ca}$ eta abar) edo magnesio aluminatoz egindakoetan $\left(\mathrm{Ni} / \mathrm{MgAl}_{2} \mathrm{O}_{4}\right)$. Burdina, kobaltoa edota metal preziatuak ere erabil daitezke katalizatzaile modura, baina zenbait desabantaila dauzkate; esaterako, burdina erraz oxidatzen da, eta metal preziatuak garestiegiak dira [26]. Katalizatzailearen pelletak hodi erreformatzaileen barruan sartzen dira (ikus 3. irudia), eta fluxu-erreformatzailea horien artean eta horien barrutik ere pasatzen da. Egia esateko, pellet horien diseinua kritikoa da (ikus 4. irudia). Alde batetik, fluxu-erreformatzailean ez dute eragin behar presio-erorketa handirik. Eta, bestetik, kanpo-gainazal handikoak izan behar dira. Izan ere, fluxu-erreformatzailea eta katalizatzailearen arteko kontaktua handitzean, erreakzio katalitikoak errazten dira.

1. taula. Metanoaren ur-lurrun bidezko erreformatzean gertatzen diren erreakzioak [29].

\begin{tabular}{|c|c|r|r|}
\hline Azalpena & Erreakzioa & \multicolumn{1}{|c|}{$\begin{array}{c}\mathrm{H}^{0} \\
(\mathrm{~kJ} / \mathrm{mol})\end{array}$} & \\
\hline $\begin{array}{c}\text { Metanoaren ur-lurrun bidezko } \\
\text { erreformatzea }\end{array}$ & $\begin{array}{c}\mathrm{CH}_{4}+\mathrm{H}_{2} \mathrm{O} \leftrightarrow \mathrm{CO}+3 \mathrm{H}_{2} \\
\mathrm{CH}_{4}+2 \mathrm{H}_{2} \mathrm{O} \leftrightarrow \mathrm{CO}_{2}+4 \mathrm{H}_{2}\end{array}$ & $\begin{array}{r}206,1 \\
165,0\end{array}$ & $(1)$ \\
\hline Ur-lurrunaren bihurketa (WGS) & $\mathrm{CO}+\mathrm{H}_{2} \mathrm{O} \leftrightarrow \mathrm{CO}_{2}+\mathrm{H}_{2}$ & $-41,1$ & $(3)$ \\
\hline \multirow{2}{*}{ Metanoaren erreformatze lehorra } & $\mathrm{CH}_{4}+\mathrm{CO}_{2} \leftrightarrow 2 \mathrm{CO}+2 \mathrm{H}_{2}$ & 247,3 & $(4)$ \\
& $\mathrm{CH}_{4}+3 \mathrm{CO}_{2} \leftrightarrow 4 \mathrm{CO}+2 \mathrm{H}_{2} \mathrm{O}$ & 330,0 & $(5)$ \\
\hline & $\mathrm{CH}_{4} \leftrightarrow \mathrm{C}+2 \mathrm{H}_{2}$ & 74,8 & $(6)$ \\
& $2 \mathrm{CO} \leftrightarrow \mathrm{C}+\mathrm{CO}_{2}$ & $-173,3$ & $(7)$ \\
& $\mathrm{H}_{2}+\mathrm{CO} \leftrightarrow \mathrm{C}+\mathrm{H}_{2} \mathrm{O}$ & $-131,1$ & $(8)$ \\
& $\mathrm{CO}_{2}+2 \mathrm{H}_{2} \leftrightarrow \mathrm{C}+2 \mathrm{H}_{2} \mathrm{O}$ & $-90,1$ & $(9)$ \\
& $\mathrm{CH}_{4}+2 \mathrm{CO} \leftrightarrow 3 \mathrm{C}+2 \mathrm{H}_{2} \mathrm{O}$ & $-187,6$ & $(10)$ \\
& $\mathrm{CH}_{4}+2 \mathrm{CO}_{2} \leftrightarrow 2 \mathrm{C}+2 \mathrm{H}_{2} \mathrm{O}$ & $-15,3$ & $(11)$ \\
\hline
\end{tabular}

1. taulan jasota daude metanoaren ur-lurrun bidezko erreformatzeari dagozkion oinarrizko hamaika erreakzio kimiko [29]. Erreakzioak itzulgarriak dira, eta, hoditik pasatzean, oreka-egoerara ailegatzen dira. Erreformatze-prozesuan, metanoaren bihurtze-tasa aldatu egiten da tenperaturaren arabera (ikus 5. irudia). Metanoaren bihurtze-maila handiagoa da tenperatura altuetan. Presioak ere eragina du oreka-egoera horretan, eta presioa handitzeak (1) ekuazioa ezkerrera lerratzen du. Azkenik, honako erreakzio 
hauen arabera gauzatzen da gas naturalaren sarrera-fluxuan proportzio txikian dauden gainerako hidrokarburoen bihurketa:

$$
\begin{aligned}
\mathrm{C}_{\mathrm{n}} \mathrm{H}_{\mathrm{m}}+\mathrm{nH}_{2} \mathrm{O} & \leftrightarrow \mathrm{nCO}+(2+\mathrm{m} / 2) \mathrm{H}_{2} \\
\mathrm{C}_{\mathrm{n}} \mathrm{H}_{\mathrm{m}} & \leftrightarrow \mathrm{nC}+(\mathrm{m} / 2) \mathrm{H}_{2}
\end{aligned}
$$

Fluxu-erreformatzailean $\mathrm{CO}_{2}$ nahikoa badago, (4) erreakzioa gertatzen da, eta prozesuan areagotu egiten da $\mathrm{CO}$-aren sorrera.

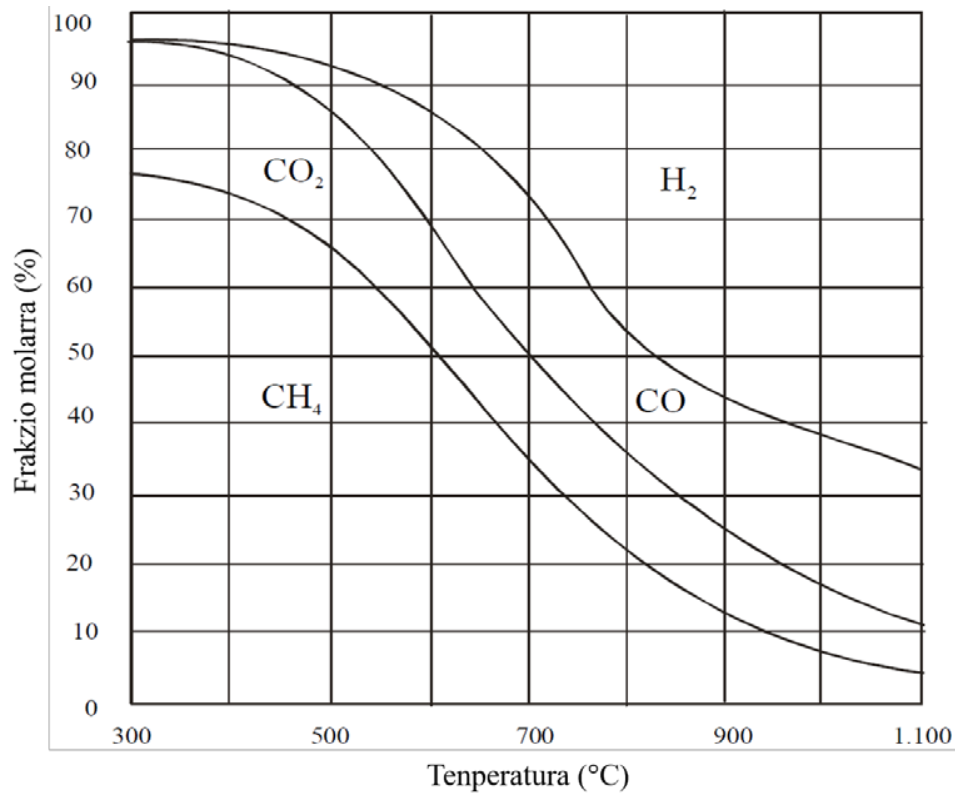

5. irudia. Sintesi-gasaren oreka-proportzioak tenperaturaren arabera [30].

Erreformatze-hodietan sartzen den ur-lurrun/metano nahasketaren proportzioa optimizatu beharreko oinarrizko parametroa da laneko tenperaturaren eta presioaren arabera. Izatez, estekiometrikoki, ur-lurrunaren eskakizuna 1,0 da metanoaren karbono atomo bakoitzeko (1). Hala ere, erlazio teoriko hori ez da bideragarria. Izan ere, erreformatzearen ohiko baldintzetan, katalizatzaile komertzialek kokearen sorrera eragin ohi dute, eta hori kaltegarria da prozesurako. Kokea sortzen duten (6-11) erreakzioak gutxitzeko, metanoa baino ur-lurrun gehiago erabiltzea komeni da (ur-lurrun/ metano proportzioa 1,7 inguruan). Gaur egungo labe erreformatzaile industrialetan ur-lurrun/metano proportzioa 2,0 eta 3,0 tartean egon ohi da, baina balio hori handiagoa izaten da instalazio zaharretan, 3,6 eta 4,0 artean $[31,26]$. Hala ere, bibliografian, 9rainoko balioak ageri dira [32]. 
Esan bezala, 1. taulako (6-11) erreakzioak koke-sorrerarekin loturik daude. Izatez, metanoaren erreformatze katalitikoaren zailtasunetariko bat da kokearen sorrera, energia-kontsumoa eta mantentze-kostuak handitzea dakarrelako [33]. Kokearen sorreraren eraginez, erreakzio katalitikoaren eraginkortasuna txikitu egiten da, katalizatzailearen gainean kokea ezartzen delako. Gainera, hodi erreformatzaileen barneko azalean ere kokea ezar daiteke, eta horrek apurka-apurka murriztu egiten du labearen errendimendua, bero-transferentziaren aurrean dagoen erresistentzia handitzen delako. Erreakzio horiek errazago gertatzen dira metanoaren bihurketa areagotzen duten tenperatura altuetan [23]. Hori dela eta, lan-tenperatura parametro kritikoa da metanoaren erreformatze-prozesuan. Normalean, erreformatze-prozesuaren amaieran, metanoaren bihurketa \% 74-85 artean egon ohi da [19]. Izatez, metanoaren ur-lurrun bidezko erreformatzeak ekoitzitako sintesi-gasaren $\mathrm{H}_{2} / \mathrm{CO}$ proportzio molarra da altuena hidrogenoa ekoizteko tekniken artean; 3tik gertu, alegia [34].

\subsection{Errekuntza-ganbera}

1. taulako erreakzio gehienak endotermikoak direnez, erreformatzeprozesuak energia asko xurgatzen du. Prozesurako beharrezkoa den energia errekuntza-ganberan sortzen da. Bertan, normalean gas naturala erretzen da, baina batzuetan beste erregai batzuk ere erabiltzen dira; hala nola, findegiko gasa, nafta eta abar. Erregaiaren eta airearen nahasketan, airearen proportzioa handiagoa da estekiometrikoa baino, erregai guztia konbustioan erretzen dela ziurtatzeko. Errekuntzaren ondorioz, nagusiki ura eta karbono dioxidoa sortzen dira, eta bero kantitate handia askatzen da. Erreakzio katalitikoak behar duen bero-fluxua eraginkorki gertatzeko, erreaktorea katalizatzailez betetako hainbat hoditan banaturik dago errekuntza-ganberaren barruan (ikus 3. irudia).
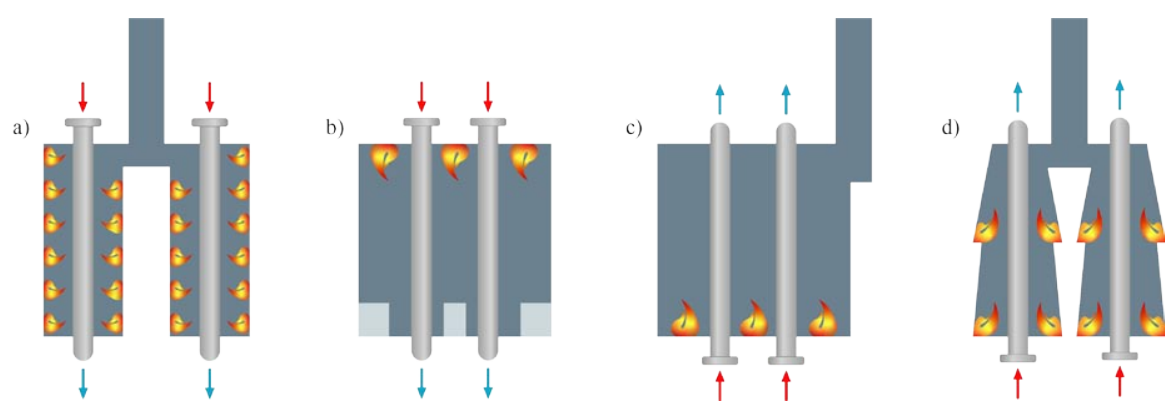

6. irudia. Industriako labe erreformatzaileen ohiko lau konfigurazioak: a) horma erradiatzailea, b) goitik berotutakoa, c) behetik berotutakoa eta d) terraza erakoa. Gezi gorriek gas naturalaren eta ur-lurrunaren sarrera adierazten dute, eta gezi urdinek sintesi-gasaren irteera. 
Labe erreformatzailearen barneko tenperatura-banaketa eta bero-fluxua erregailuen kokapenaren araberakoak dira. Izatez, labe erreformatzaileen konfigurazioen sailkapena erregailuen kokapenaren araberakoa izaten da [35]. Gaur egun, ekoizpen industrialean lau motatako labeak erabili ohi dira (ikus 6. irudia): horma erradiatzaileduna, goitik berotutakoa, behetik berotutakoa eta terraza-hormakoa. Lau konfigurazio horien artean ageri diren desberdintasun tekniko nagusiak hauek dira: errekuntza-ganberaren tamaina eta diseinua, hodi erreformatzaileen antolamendua, hodien barruko eta kanpoko diametroa, eta erregailuen egitura eta banaketa. Izatez, diseinu guztietan, energia-erabilera optimizatzea eta hodi erreformatzaileen bizitza luzatzea dira helburu nagusiak. Hori lortuz gero, labearen inbertsio- eta erabilera-kostuak murriztu egiten dira. Labe-konfigurazio bakoitzak tenperatura eta bero-fluxuaren berezko profila du. Adibidez, goitik berotutako labeak tenperatura-banaketa ez-uniformea sortzen du errekuntza-ganberan. Bero kantitate handia transferitzen da hodi erreformatzaileetara fluxuaren sarreratik gertu, eta poliki-poliki bero-transferentzia murriztuz doa hodian zehar. Behetik berotutako labeak, aldiz, bero-fluxu uniformea dauka hodi erreformatzaileen luzera osoan zehar. Bestalde, horma terraza eran daukan labea behetik berotutakoaren bertsio eraldatua da. Azkenik, horma erradiatzailedun labeak errekuntza-ganberaren barruko tenperatura-banaketa kontrolatzeko malgutasun handiagoa du.

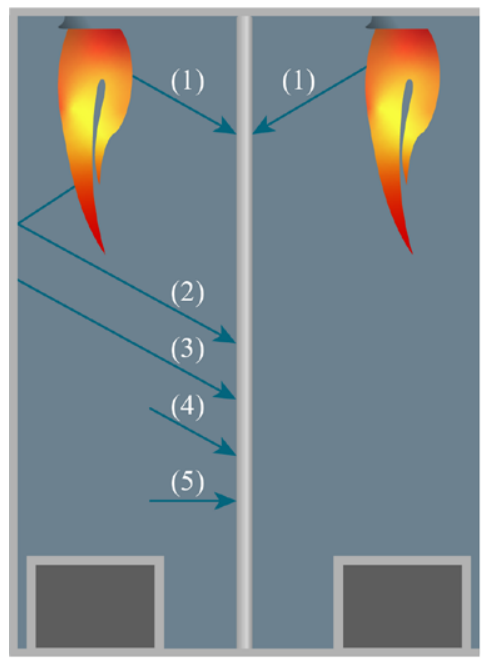

(1) Zuzeneko erradiazioa sugarretik.

(2) Islatutako erradiazioa sugarretik.

(3) Erradiazioa hormatik eta material erregogorretik.

(4) Erradiazioa errekuntza-gasetatik.

(5) Bero-transferentzia konbekzio eta kondukzioagatik.

7. irudia. Labe erreformatzailearen barruko energia-transferentziako prozesurik garrantzitsuenak.

Goitik berotutako labeetan, errekuntza-prozesuan askatutako energiaren \% 40-50 inguru erreformatze-hodiek xurgatzen dute, gehienbat hodia- 
ren goiko zatian [22, 23]. Energia horretatik \% 95 inguru erradiazioaren bitartez transmititzen da hodietara [36, 37], eta gainontzekoa konbekzioaren eta kondukzioaren bitartez jasotzen dute. $\mathrm{H}_{2} \mathrm{O}$ eta $\mathrm{CO}_{2}$ bezalako errekuntza-produktuek erradiazio termikoa xurgatzen eta igortzen dute; beraz, labearen barruko gasak ezin dira ingurune gardentzat hartu (ikus 7. irudia). Labe erreformatzailean erradiazioagatik gertatzen diren bero-transferentziak eraginkorragoak izateko, komeni da errekuntza-ganberaren barneko azalek emisibitate handia edukitzea [38]. Hori lortzeko, gainazal-tratamenduak eman daitezke hodietan eta labearen paretetan [39].

Aurretik aipatu dugunez, hodi erreformatzaileek diseinu-tenperatura optimoa daukate degradazio azkarra ekiditeko. Normalean, hodiaren azaleko tenperatura hartzen da kontrolerako erreferentzia modura, neurtzeko errazagoa delako. Hodiaren azaleko tenperatura diseinatutako funtzionamendu-balioaren gainetik $20{ }^{\circ} \mathrm{C}$ handitzeak hodiaren aurreikusitako bizitza erdira murriztea ekar dezake [24]. Are gehiago, hodi erreformatzailearen azaleko tenperaturak diseinu-balioa nabarmen gainditzen duenean, hodi erreformatzailearen pareta hautsi egin liteke, prozesu guztia geldituz eta diru-galera handiak eraginez (labea egun bat geldituta izateak 350 mila eta milioi bat dolarreko kostua dauka [23], eta hodi guztiak berriro jartzea labearen hasierako kostuaren \% 10 ingurukoa da [1]). Hori dela eta, komeni da labe erreformatzailearen barruan tenperatura-banaketa uniformea egotea, hodien degradazioa ekiditeko eta bero-transferentzia eraginkorki gertatzeko. Hala ere, termografia infragorriaren bitartez egindako neurketetan, tenperatura-banaketa ez-uniformeak behatu izan dira hainbat labe industrialetan [40]. Tenperatura-banaketa ez-uniformearen arrazoi nagusia errekuntza-ganberan errekuntza-produktuen abiadura-banaketa asimetrikoa izan ohi da [40]. Izatez, labe erreformatzaileen errekuntza-ganberan, errekuntzagasen fluxua turbulentua izan ohi da (Reynolds-en zenbakia $\approx 6 \cdot 10^{5}$ ) [33].

\subsection{Ur-lurrunaren bihurketa eta hidrogenoaren bereizketa}

Labe erreformatzailetik ateratzen den sintesi-gasaren bolumeneko \% 5 edo gehiago (ca. \% 10) karbono monoxidoa izan daiteke. CO kantitatea txikitzeko eta, aldi berean, hidrogeno-proportzioa are gehiago handitzeko, ur-lurrunaren bihurketa-erreakzioa, WGS erreakzioa, aplikatzen da (ikus (3) ekuazioa) [41]. Termodinamikaren ikuspegitik, presioak ia ez du eraginik erreakzio honetan. Baina, tenperatura baxuko baldintzek hidrogenoproportzioa nabarmen handitzea errazten dute erreakzioaren izaera exotermikoagatik. Gainera, erreakzio honen eraginkortasuna asko hobetu daiteke katalizatzaile egokiekin. Berez, WGS erreakzioa sinplea da, eta, gainera, urteetan zehar ikerketa zabalak gauzatu izan dira ondo ezaugarritzeko. Hala ere, WGS erreakzio-mekanismoa polemikoa eta korapilatsua da oraindik ere, katalizatzaileek lan-baldintzen aldaketa txikiekiko duten sentsibilitatea dela eta. 
Gaur egun, ur-lurrunaren bihurketa-prozesua etapa bakarrean gauzatu daiteke WGS unitatean, edo bi etapatan:

- Tenperatura altuko bihurketa. Prozesu hau erreaktore adiabatikoetan gauzatzen da, eta bihurketaren hasierako etaparako erabili ohi da. Bihurketa-prozesua $310-450{ }^{\circ} \mathrm{C}$ tenperatura-tartean gertatu ohi da. Tenperatura altuko bihurketan $\mathrm{Fe}-\mathrm{Cu}-\mathrm{Cr}$ katalizatzaileak erabiltzen dira. Etapa horren bitartez, CO sintesi-gasaren bolumena \% 10etik $\%$ 3ra jaitsi ohi da.

- Tenperatura baxuko bihurketa. Prozesu hau bihurketaren bigarren etaparako erabiltzen da, bihurketa-proportzio maximoa lortuz. $185-250{ }^{\circ} \mathrm{C}$ tenperatura-tartean gertatzen da. Ohiko katalizatzaile komertziala $\mathrm{Cu}-\mathrm{ZnO}-\mathrm{Al}_{2} \mathrm{O}_{3}$ izaten da, baina, batzuetan, $\mathrm{Cu}-\mathrm{ZnO}$ $\mathrm{Cr}_{2} \mathrm{O}_{3}$ katalizatzailea ere erabiltzen da. Bigarren etapa honen amaieran, karbono monoxidoa 500 ppm ingurukoa izan ohi da sintesi-gasean.

CO-aren kantitatea gehiago jaitsi nahi badugu, lehentasunezko oxidazioko (PrOx) erreaktorea edo CO-aren aurrean selektiboa den metanazioerreaktorea erabil daiteke.

Ondoren, sintesi-gasetik purutasun handiko hidrogenoa lortzeko prozesuak aplikatzen dira. Tekniken artean, gaur egun gehien erabiltzen den prozesua Presio Aldakorreko Absortzioa (ingelesez, Pressure Swing Absortion, PSA) da. Horretarako, presio altuko gordailuetan jarritako karbonozko pelletek gas guztiak xurgatzen dituzte, hidrogenoa izan ezik. Hortaz, sintesi-gasa bertatik igarotzean hidrogenoa baino ez da pasatzen. PSA unitate industrialek purutasun handiko hidrogenoa sor dezakete $(99,999+\%)$. Hori, ordea, hidrogeno-berreskurapen txikiarekin lotuta dago (\% 70-75), eta horrek eragin negatiboa du sortutako hidrogenoaren kostuan. Gainera, berotegi-efektuko gas handienetakoa $\left(\mathrm{CO}_{2}\right)$ da prozesu honen azpiproduktu nagusia. Gaur egun, $\mathrm{CO}_{2}$ hori eguratsera askatzen da; izan ere, PSA prozesua ez dago era egokian diseinatuta ekonomikoki $\mathrm{CO}_{2}$ harrapatzeko.

Momentu honetan, beste teknika batzuk ikertzen eta garatzen ari dira, PSA prozesuak dituen gabeziak gainditzeko. Adibidez, ikertzaile akademiko eta industrialek arreta handia jarri dute mintz bidezko bereizketan. Urte askotako garapenaren ondoren, industria askotan erabiltzen hasia da jadanik; hala nola, ur-tratamenduetan eta gasen bereizketan. Izatez, hidrogenoa bereizteko beste teknologia batzuekin alderatuta, abantaila ugari ditu mintz bidezko gas-bereizketak, besteak beste, funtzionamendu sinpletasuna, energia-eskari txikia, aztarna txikia eta etengabeko funtzionamendua. 


\section{ERAGINKORTASUN TERMIKOA}

Industria kimikoko energia-kontsumitzaile handienetakoak dira findegietako labeak, atmosferara $\mathrm{CO}_{2}$ gas-isuri handiak eraginez. Horregatik, labe horietan oso garrantzitsua da bero-trukaketaren prozesuak eraginkorrak izatea, energia-kontsumoa eta negutegi-efektuko gasen isuriak murrizteko. Hori dela eta, funtsezkoa da labeen diseinua eta funtzionamendua optimizatzea. Azken urteetan, ahalegin aipagarriak egin dira hidrogenoaren ekoizpen mota honen jasangarritasuna hobetzeko [42, 43]. Garapen horiek gehienbat hiru esparrurekin lot daitezke [44]: prozesuaren eraginkortasuna, ingurumenaren gaineko eragina, eta segurtasuna. Ikerketa-lan asko burutu dira; adibidez, prozesuaren energia- eta exergia-balantzeak aztertzeko [45, 46], kostuak murrizteko [47], alderdi operatiboak hobetzeko, hala nola erreaktore $[48,49]$ edo katalizatzaile [26] berrien garapena eta abar.

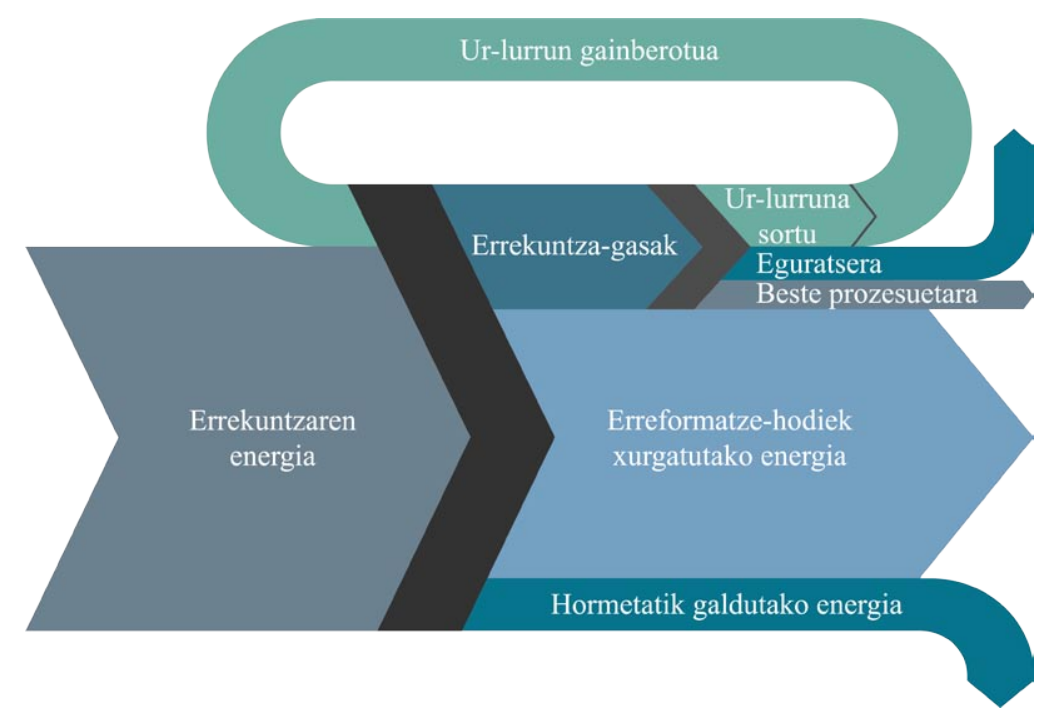

8. irudia. Labe erreformatzaileko energien fluxu-diagrama.

Labe erreformatzailean gertatzen diren energia-fluxuak 8. irudian ageri dira. Erregailuetako konbustioan askatzen den energia da labearen energia-iturri nagusia. Hala ere, tenperatura altuko ur-lurrunarekin elikatzen da erreformatze-prozesua, eta hori ere energia-iturri modura hartzen da. Logikoa denez, errekuntza-energiaren zatirik garrantzitsuena erreformatze-prozesua elikatzeko erabiltzen da, \% 40-50 inguru [22, 23]. Errekuntza-energiaren zati txiki batek hormetatik alde egiten du (esaterako, goitik berotutako labeetan, errekuntzan askatutako energiaren \% 2-5 labearen hormetatik galtzen da [24]). Azkenik, tenperatura altuko errekuntza-gasek 
daramaten energiaren zati bat, \% 35 inguru, konbekzio-dorrean ur-lurruna ekoizteko erabiltzen da (erreformatze-prozesurako edo plantako beste prozesuetarako), eta gainerakoa tximiniatik galtzen da, \% 20-25 inguru [23].

Metanoaren ur-lurrun bidezko erreformatze-prozesuaren eraginkortasun termikoa, $\eta$, zenbatesteko, honako balantze energetiko hau erabili ohi da $[13,50]$ :

$$
\eta=100\left(\frac{\text { Lortutako energia }}{\text { Erabilitako energia }}\right)
$$

Hala ere, praktikan, kontuan hartzen diren energia-fluxuen arabera, modu desberdinetan kalkulatzen da. Eraginkortasun energetikoaren kalkulurik sinpleena egiteko, labe erreformatzailean gertatzen diren lau energia-fluxu aztertzen dira. Alde batetik, prozesuan erabilitako energia kalkulatzeko, erregailuetan erretako metano-fluxua, $F_{\mathrm{CH}_{4}}^{\text {errega }}(\mathrm{kg} / \mathrm{h})$, eta erreformatze-hodietan sartutako metano-fluxua, $F_{\mathrm{CH}_{4}}^{\text {errefor }}(\mathrm{kg} / \mathrm{h})$, hartzen dira kontuan. Beste aldetik, erreformatze-prozesuan lortutako energia kalkulatzeko, sintesi-gasean lortzen diren hidrogeno-fluxua, $F_{H_{2}}(\mathrm{~kg} / \mathrm{h})$, eta karbono monoxidoaren fluxua, $F_{C O}(\mathrm{~kg} / \mathrm{h})$, erabiltzen dira. Gauzak horrela, erreformatze-prozesuan parte hartzen duten konposatu kimikoen goi bero-ahalmena, GBA (kJ/kg), erabiltzen bada, (14) ekuazioa honela geratzen da:

$$
\eta_{\mathrm{GBA}}=100\left(\frac{F_{\mathrm{H}_{2}} \cdot \mathrm{GBA}_{\mathrm{H}_{2}}+F_{\mathrm{CO}} \cdot \mathrm{GBA}_{\mathrm{CO}}}{\left(F_{\mathrm{CH}_{4}}^{\text {errega }}+F_{\mathrm{CH}_{4}}^{\text {errefor }}\right) \cdot \mathrm{GBA}_{\mathrm{CH}_{4}}}\right) .
$$

Aldiz, konposatu kimikoen behe bero-ahalmena, BBA (kJ/kg), erabiltzen bada, honela kalkulatzen da:

$$
\eta_{\mathrm{BBA}}=100\left(\frac{F_{\mathrm{H}_{2}} \cdot \mathrm{BBA}_{\mathrm{H}_{2}}+F_{\mathrm{CO}} \cdot \mathrm{BBA}_{\mathrm{CO}}}{\left(F_{\mathrm{CH}_{4}}^{\text {errega }}+F_{\mathrm{CH}_{4}}^{\text {errefor }}\right) \cdot \mathrm{BBA}_{\mathrm{CH}_{4}}}\right) .
$$

Labe erreformatzailearen ostean, konbekzio-dorre bat egon ohi da, errekuntza-gasen energia zati bat berreskuratzeko. Konbekzio-dorrean berreskuratutako energia hori ur-lurruna sortzeko erabili ohi da, $E_{U r \text {-lurruna }}(\mathrm{kJ} / \mathrm{h})$. Energia-fluxu hori kontuan hartuz gero, prozesuaren eraginkortasun energetikoa asko handitzen da:

$$
\eta_{\mathrm{GBA}}=100\left(\frac{F_{\mathrm{H}_{2}} \cdot \mathrm{GBA}_{\mathrm{H}_{2}}+F_{\mathrm{CO}} \cdot \mathrm{GBA}_{\mathrm{CO}}}{\left(F_{\mathrm{CH}_{4}}^{\text {errega }}+F_{\mathrm{CH}_{4}}^{\text {erref }}\right) \cdot \mathrm{GBA}_{\mathrm{CH}_{4}}-E_{\mathrm{Ur}-\text { luruna }}}\right) \text {. }
$$


Aurretik esan dugunez, labe erreformatzailearen lan-baldintzen arabera aldatzen dira irteerako sintesi-gasaren proportzioak, eta, horren ondorioz, labearen eraginkortasun termikoa ere bai [51]. Bibliografiaren arabera, metanoaren erreformatze-labeetan $\eta_{\mathrm{GBA}} \% 70$ eta $\% 85$ artean egon ohi da $[50,11]$; eraginkortasun handienetarikoa duena da hidrogenoa ekoizteko erabiltzen diren tekniken artean.

\section{LABE ERREFORMATZAILEEN MODELIZAZIOA}

Metanoaren erreformatze-prozesua kontrolatzeko eta optimizatzeko hainbat sentsore daude labe erreformatzailean zehar kokaturik. Sentsore batzuek prozesuaren parametroak kontrolatzen dituzte; hau da, erreformatze-hodietan sartu eta bertatik ateratzen diren fluxuen ezaugarriak neurtzen dituzte (hala nola, presioa, tenperatura, konposizioa, eta abar). Baina hori ez da nahikoa; erregailu baten errekuntza-prozesua ez bada zuzena, barne-tenperaturaren banaketa ez da uniformea izango, eta prozesua eta hodiak kaltetu egin daitezke. Hori dela eta, errekuntza-ganberan gertatzen denaren jarraipena egitea ere garrantzitsua da, eta beste sentsore batzuk daude hor kokatuta. Zoritxarrez, errekuntza-ganbera tenperatura oso altuetan dago (tenperaturak hainbat lekutan $2.000 \mathrm{~K}$ erraz gainditu dezake [37]), eta giro oso oxidatzailea da. Horrek azkartzen du termopareen degradazioa, eta, horregatik, ez dira asko erabiltzen. Azken urteotan, asko zabaldu da termografia infragorriaren erabilera errekuntza-ganberako barne-tenperatura kontrolatzeko [52]. Tamalez, neurketa infragorriek ziurgabetasun handia daukate, barruko elementuen emisibitatea ondo ezaugarrituta ez egoteagatik eta efektu optikoengatik [53]. Horren guztiaren ondorioz, errekuntza-ganberan gertatzen diren fenomenoak ondo aztertzeko, sarritan jo izan da simulazioetara $[54,55]$.

Labe erreformatzaileen jokaera deskribatzeko, hiru motatako eredu teorikoak garatu izan dira:

- Erreformatze-prozesua simulatzen duten ereduak. Labe erreformatzaile industrialen modelizazio eta kontrolerako lau erreakzioko eskema sinplifikatua erabiltzen da normalean; (1-4) erreakzioak, alegia [22]. Erreformatze-prozesua soilik simulatzen duten ereduak oso garrantzitsuak dira petrolio-industrian, oso lagungarriak direlako plantaren eguneroko kudeaketarako [56]. Izan ere, prozesuaren parametroen etengabeko iragarpena ahalbidetzen dute, eta, horrela, kontrol-parametroak egokitu eta eraginkortasun termikoa hobetu daiteke. Gaur egun, eredu horien emaitzak zehaztasun handikoak dira, eta horien erabilerari esker labearen energia-kontsumoa \% 2-3 murriztu daiteke [22]. Eredu horiek hainbat software komertzialetan inplementatuta daude; hala nola, Aspen Hysis ${ }^{\circledR}$, Reform-3PC, RIPIRefSim eta (Pycoso) Air Liquide. Zoritxarrez, programa informatiko 
horien jatorrizko kodea ez da publikoa, eta, horrela, kutxa beltz baten moduan jokatzen dute.

- Errekuntza-ganberako eredu fluidomekanikoak. Aspaldian landutako eredu fluidomekanikoetan, baztertu egiten dira erreformatze-katalitikoaren xehetasun gehienak [57, 58]. Hau da, erreformatze-hodien batez besteko ezaugarriak kontuan hartuta, errekuntza-ganberako prozesuak aztertzen dira: errekuntza, erradiazioa eta fluidoen zirkulazioa. Adibidez, 1990eko hamarkadaren amaieran konturatu ziren errekuntza-ganberan birzirkulazio-fluxuak zeudela goitik berotutako hainbat unitatetan. Birzirkulazio-fluxu horien eraginez, labe erreformatzailearen barneko tenperatura-banaketa ez zen uniformea. Eredu fluidomekanikoen bitartez, jokaera berezi hori aztertu eta konponbideak proposatu ziren [59]. Gaur egun, ia ez dira lantzen horrelako ereduak.

- Labe erreformatzailea bere osotasunean simulatzen duten ereduak. Eredu hauek aurreko bi ereduen konbinaziotzat har daitezke. Izan ere, errekuntza-ganberako eta hodi erreformatzaileen barruko prozesuak akoplatzen dira kalkuluetan [24, 37, 60]. Eredu hauen konplexutasuna handia da, baina aurresateko duten gaitasunak ahalbidetu du beren erabilera zabala. Hasieran, labeen diseinu eta optimizaziorako simulazio parametrikoak gauzatu izan badira ere, gaur egun, eredu hauek gehienbat labe erreformatzailearen kontrol dinamikorako bideratzen dira. Horrelako ereduak garatzeko, zenbakizko kalkuluko software komertzialak erabili ohi dira; adibidez, COMSOL Multiphysics ${ }^{\circledR}$, STAR CCM+, ANSYS eta MATLAB .

\section{GAUR EGUNGO ERRONKAK}

Hidrogeno merkea eta garbia beharrezkoa da hidrogenoan oinarritutako ekonomia martxan jartzeko. Gaur egun, hidrogenoa ekoizteko gutxienez hamalau teknologia desberdin daude, eta, beren artean, metanoaren ur-lurrun bidezko erreformatzea da teknologiarik merkeena [19]. Izatez, momentu honetan, gas naturala da hidrogenoa ekoizteko lehengai merkeenetarikoa eta erabiliena. Baina, metanoaren ur-lurrun bidezko erreformatzea teknologia heldua izanik ere, hainbat erronka ditu erreaktiboen ezaugarri eta erreakzioen termodinamikagatik: energia-kontsumo handia, produkzio-kostu handia, erreakzio-baldintza gogorrak, erreakzio-eraginkortasun txikia eta prozesuaren egonkortasun txikia. Zehazki, gaur egun, hiru eremutan ageri dira teknologia honen erronkak:

1. Katalizatzaileen diseinuak hobekuntza behar du oraindik ere [7, 26]. Alde batetik, metal nobleen katalizatzaileek (adibidez, Ru eta Rh) erreformatze katalitikoan aktibitate kimiko handia dute egonkorta- 
sun onarekin. Hala ere, metal nobleen kostuak eta eskuragarritasunak mugatzen dute haien erabilpena. Bestalde, nikelean oinarrituriko katalizatzaile komertzialek desaktibazio handia jasan dezakete lan-baldintzen arabera, sinterizazioa eta koke-erakuntza gerta baitaitezke.

2. Metanoaren erreformatze-prozesuak $\mathrm{CO}_{2}$-a ere sortzen du, batez ere hidrogenoa ekoizteko WGS unitatearekin batera erabiltzen denean (9-14 $\mathrm{kg} \mathrm{CO} / 2 \mathrm{~kg} \mathrm{H}_{2}$ ) [7]. $\mathrm{CO}_{2}$-a atmosferara isurtzeak berotegiefektuaren gainean eragin handia duenez, harrapatu eta bahitu egin behar da. Zoritxarrez, $\mathrm{CO}_{2}$-aren manipulazioak prozesuaren kostua areagotzen du. Azken garaietan, $\mathrm{CO}_{2}$ eta $\mathrm{CH}_{4}$ berotegi-efektuko gasak aldi berean sintesi-gas bihurtzeko gai diren teknologiak aztertzen eta garatzen ari dira. Adibidez, horien artean dago metanoaren $\mathrm{CO}_{2}$-aren erreformatze lehorra [34].

3. Metanoa oso egonkorra da eta, horregatik, zaila da aktibatzeko. Erreformatze-prozesua tenperatura eta presio altuetan gertatu behar da, eta horrek masa-transferentzia eta bero-transferentzia arazoak ere sortzen ditu. Erreformatze-prozesuan energia-kontsumoa murrizteko, gaur egun ekoizpen industrialeko unitateetan eraldaketa digitala gauzatzen ari da, 4.0 industriaren helburuen arabera [22, 31]. Horretarako, oso lagungarriak dira erreformatze-prozesua simulatzen duten eredu teorikoak. Izatez, biki digitala (ingelesez, digital twin) deritzon unitate birtuala sortzen da eredu teorikoen laguntzaz, eta inteligentzia artifizialaren bitartez eraginkorrago kudeatzeko aukera dago [1, 61, 62]. Horrelako estrategien bitartez, hainbat arazo saihestu daitezke; adibidez, hodien eta beste elementuen degradazioa edo tenperatura-desorekengatiko apurketa. Izan ere, erregailu bakoitzaren erregai-fluxua kontrolatu daiteke tenperatura-banaketa uniformea lortzeko [1].

\section{BIBLIOGRAFIA}

[1] TRAN, A., PONT, M., CROSE, M. eta CHRISTOFIDES, P.D. 2018. «Realtime furnace balancing of steam methane reforming furnaces». Chem. Eng. Res. Des., 134, 238-256.

[2] TÖPLER, J. eta LEHMANN, J. (ed.). 2016. Hydrogen and fuel cell. Technologies and market perspectives. Springer-Verlag. Heidelberg.

[3] Repsolek eta Petronorrek deskarbonizaziorako puntako bi industria-proiektu burutuko dituzte Euskadin. 2020. Eskuragarri: https://petronor.eus/ eu/2020/06/repsolek-eta-petronorrek-deskarbonizaziorako-puntako-bi-industria-proiektu-burutuko-dituzte-euskadin/ (azken kontsulta: 2020-12-31).

[4] STOLTEN, D. eta EMONTS, B. (ed.). 2016. Hydrogen science and engineering. Materials, processes, systems and technology. Wiley-VCH Verlag, Weinheim. 
[5] ROSTRUP-NIELSEN, J.R. eta CHRISTIANSEN, L.J. 2011. Concepts in syngas manufacture. Catalytic Science Series. Imperial College Press, London.

[6] ABDI, H., NEZHAD R.R. eta SALEHIMALEH, M. Fuell cells. GHAREHPETIAN, G. eta AGAH, S.M.M. (ed.). 2017. Distributed Generation Systems. Butterworth-Heinemann, Kidlington.

[7] CHEN, L., QI, Z., ZHANG, S., SU, J. eta SOMORJAI, G.A. 2020. «Catalytic hydrogen production from methane: A review on recent progress and prospect». Catalysts, 10,858.

[8] PASHCHENKO, D. 2019. «Combined methane reforming with a mixture of methane combustion products and steam over a Ni-based catalyst: An experimental and thermodynamic study». Energy, 185, 573-584.

[9] SHERIF, S.A., GOSWAMI, D.Y., STEFANAKOS, E.K. eta STEINFELD, A. (ed.). 2014. Handbook of hydrogen energy. CRC Press-Taylor \& Francis Group, Boca Ratón.

[10] IBRAHIM, A.A. 2018. Hydrogen production from light hydrocarbons. Advances in hydrogen generation technologies. IntechOpen, London.

[11] SHAH, M., MONDAL, P., NAYAK, A.K. eta BORDOLOI, A. Hydrogen from natural gas. MONDAL, P. eta DALAI, A.K. (ed.). 2017. Sustainable utilization of natural resources. CRC Press, Boca Ratón.

[12] GANDÍA, L.M., ARZAMENDI, G. eta DIÉGUEZ, P.M. Renewable hydrogen energy: An overview. GANDÍA, L.M., ARZAMENDI, G. eta DIÉGUEZ, P.M. (ed.). 2013. Renewable hydrogen technologies. Production, purification, storage, applications and safety. Elsevier, Amsterdam, 1-17.

[13] AYASTUY, J.L. 2008. «Hidrogeno energia-bektorea I. Iturriak eta ekoizpena». EKAIA, 21, 65-88.

[14] REMIRO, A., OAR-ARTETA, L. eta GAYUBO, A.G. 2016. «Hidrogenoekoizpena bio-oilaren erreformatze katalitikoaren bidez». EKAIA, 32, 35-50.

[15] ROSTRUP-NIELSEN, J.R. Catalytic Steam Reforming. ANDERSON, J.R. eta BOUDART, M. (ed.). 1984. Catalysis, Springer-Verlag, Berlin, 1-117.

[16] MURKIN, C. eta BRIGHTLING, J. 2016. «Eighty years of steam reforming». Johnson Matthey Technol. Rev, 60 (4), 263-269.

[17] ROSTRUP-NIELSEN, J.R. 2015. «An industrial perspective on the impact of Haldor Topsøe on research and development in synthesis gas production». J. Catal., 328, 5-10.

[18] ROSTRUP-NIELSEN, J.R. Steam reforming of hydrocarbs. A historical prespective. BAO, X. eta XU, Y. (ed.). 2004. Studies in Surface Science and Catalysis, 147, Elsevier, Amsterdam, 121-126.

[19] NIKOLAIDIS, P. eta POULLIKKAS, A. 2017. «A comparative overview of hydrogen production processes». Renew. Sust. Energ. Rev., 67, 597-611.

[20] HÄRING, H.-W. (ed.). 2008. Hydrogen and carbon monoxide: Synthesis gases (chapter 5). In Industrial gases processing.Wiley-VCH Verlag $\mathrm{GmbH} \&$ Co. KGaA, Weinheim, 135-184.

[21] HYMAN, M. 1968. «Simulate methane reformer reactions». Hydrocarb. Process., 47 (7), 131-137. 
[22] ZEČEVIĆ, N. eta BOLF, N. 2020. «Integrated method of monitoring and optimization of steam methane reformer process». Processes, 8 (4), 408.

[23] 2019. «Controlling the stresses of the primary reformer». Nitrogen + Syngas, 359, 32-49.

[24] LATHAM, D. 2008. Mathematical modeling of an industrial steam methane reformer. M.Sc.E. Thesis, Department of Chemical Engineering, Queen's University, Ontario, Canada.

[25] AFANDIZADEH, S. eta FOUMENY, E.A. 2001. «Design of packed bed reactors: guides to catalyst shape, size and loading selection». Appl. Therm. Eng., 21, 669-682.

[26] MELONI, E., MARTINO, M. eta PALMA, V. 2020. «A short review on Ni based catalysts and related engineering issues for methane steam reforming». Catalysts, 10, 352.

[27] WEI, Q., GAO, X., WANG, L. eta MA, Q. 2020. «Rational design of nickelbased catalyst coupling with combined methane reforming to steadily produce syngas». Fuel, 271, 117631.

[28] ARAMOUNI, N.A.K., TOUMA, J.G., TARBOUSH, J.G., ZEAITER, J. eta AHMAD, M.N. 2018. «Catalyst design for dry reforming of methane: Analysis review». Renew. Sust. Energ. Rev., 82, 2570-2585.

[29] PASHCHENKO, D. 2018. «First law energy analysis of thermochemical waste-heat recuperation by steam methane reforming». Energy, 143, 478487.

[30] ZUBIZARRETA, J.I. 2008. «Hidrógeno, gas de síntesis y derivados». http:// www.diquima.upm.es/old_diquima/docencia/tqindustrial/docs/cap2_hidrogeno.pdf (Azken kontsulta: 2021-02-24).

[31] ZEČEVIĆ, N. eta BOLF, N. 2020. «Advanced operation of the steam methane reformer by using gain-scheduled model predictive control». Ind. Eng. Chem. Res., 59, 3458-3474.

[32] ACUÑA, A., FUENTES, C. eta SMITH, C.A. 1999. «Dynamic simulation of a furnace of steam reforming of natural gas». CT\&F-Ciencia, Tecnología y Futuro, 1 (5), 35-44.

[33] PEDOT, T., CUENOT, B., RIBER, E. eta POINSOT, T. 2016. «Coupled heat transfers in a refinery furnace in view of fouling prediction». J. Heat Transfer, 138, 072101.

[34] GHONEIM, S.A., EL-SALAMONY, R.A. eta EL-TEMTAMY, S.A. 2016. «Review on innovative catalytic reforming of natural gas to syngas». World J. Eng. Technol., 4, 116-139.

[35] WIDRIG, J. 2016. «Reformer performance and tube life management». Nitrogen+Syngas, 339, 38-56.

[36] YU, Z., CAO, E., WANG, Y., ZHOU, Z. eta Z. DAI. 2006. «Simulation of natural gas steam reforming furnace». Fuel Process. Technol., 87, 695-704.

[37] TRAN, A., AGUIRRE, A., DURAND, H., CROSE, M. eta CHRISTOFIDES, P.D. 2017. «CFD modeling of a industrial-scale steam methane reforming furnace». Chem. Eng. Sci., 171, 576-598. 
[38] GROTE, M., POHL, E., SAPTOGINO, P.H. eta DIARRA, D. 2017. «Impact of solid body emissivity on radiative heat transfer efficiency in furnaces - a numerical study». Energy Procedia, 120, 628-634.

[39] HEYNDERICKX, G. J. eta NOZAWA, M. 2004. «High-emissivity coatings on reactor tubes and furnacewalls in steam cracking furnaces». Chem. Eng. Sci., 59, 5657-5662.

[40] ZHENG, D., WU, B., FLEITZ, J., TRAJKOVSKI, R. eta ZHOU, C.Q. 2010. «CFD simulation of a hydrogen reformer furnace». Proceedings of the 14th International Heat Transfer Conference (IHTC14), Washington.

[41] EBRAHIMI, P., KUMAR, A. eta KHRAISHEH, M. 2020. «A review of recent advances in water-gas shift catalysis for hydrogen production». Emergent Materials, 3, 881-917.

[42] BOYANO, A., BLANCO-MARIGORTA, A.M., MOROSUK, T. eta TSATSARONIS, G. 2011. «Exergoenvironmental analysis of a steam methane reforming process for hydrogen production». Energy, 36, 2202-2214.

[43] TUGNOLI, A., LANDUCCI, G. eta COZZANI, V. 2008. «Sustainability assessment of hydrogen production by steam reforming». Int. J. Hydrogen Energy, 33, 4345-4357.

[44] NAZIR, S.M., CLOETE, J.H., CLOETE, S. eta AMINI, S. 2019.«Efficient hydrogen production with $\mathrm{CO}_{2}$ capture using gas switching reforming». Energy, 185, 372-385.

[45] DIMOPOULOS, G.G., STEFANATOS, I.C. eta KAKALIS, N.M.P. 2013. «Exergy analysis and optimisation of a steam methane pre-reforming system». Energy, 58, 17-27.

[46] SIMPSON, A.P. eta LUTZ, A.E. 2007.«Exergy analysis of hydrogen production via steam methane reforming». Int. J. Hydrog. Energy, 32, 48114820 .

[47] MUELlER-LANGER, F., TZIMAS, E., KALTSCHMITT, M. eta PETEVES, S. 2007. «Techno-economic assessment of hydrogen production processes for the hydrogen economy for the short and medium term». Int. J. Hydrog. Energy, 32, 3797-3810.

[48] NGO, S.I., LIM, Y.-I., KIM, W., SEO, D.J. eta YOON, W.L. 2019. «Computational fluid dynamics and experimental validation of a compact steam methane reformer for hydrogen production from natural gas». Appl. Energy, 236, 340-353.

[49] HONG, S.K., DONG, S.K., HAN, J.O. eta LEE, J.S. 2013. «Numerical study of effect of operating and design parameters for design of steam reforming reactor». Energy, 61, 410-418.

[50] HOLLADAY, J.D., HU, J., KING, D.L. eta WANG, Y. 2009. «An overview of hydrogen production technologies». Catalysis Today, 139, 244-260.

[51] YIN, H., JIANG, S., ZHANG, Y. eta JU, H. 2006. «Thermodynamic analysis of thermal efficiency of HTR-10 hydrogen production system». J. Nucl. Sci. Technol., 43 (10), 1188-1193. 
Gaur egungo hidrogeno-ekoizpena: metanoaren ur-lurrun bidezko erreformatzea

[52] SAUNDERS, P. 2007. Radiation thermometry. Fundamentals and applications in the petrochemical industry. Spie Press, Bellingham.

[53] FUENTE, R., CAMPILLO-ROBLES, J.M., OLAIZOLA, I., FERNÁNDEZ, A., ARZUA, I., ECHÁNIZ, T. eta LÓPEZ, G.A. 2020. «Petrochemical furnace precise temperature monitoring aided by thermographic data corrections». 15th Quantitative InfraRed Thermography Conference - QIRT 2020, Porto (Portugal).

[54] URIZ, I., ARZAMENDI, G., DIÉGUEZ, P.M. eta GANDÍA, L.M. Computational fluid dynamics as a tool for designing hydrogen energy technologies. GANDÍA, L.M., ARZAMENDI, G. eta DIÉGUEZ, P.M. (ed.). 2013. Renewable hydrogen technologies. Production, purification, storage, applications and safety. Elsevier, Amsterdam, 401-435.

[55] LORRA, M.A. eta CHEN, S.X. CFD-based combustion modeling. BAUKAL, J.C.E. (ed.). 2013. The John Zink Hamworthy Combustion Handbook. CRC Press, Boca Raton. 353-380.

[56] OLIVIERI, A. eta VEGLIO, F. 2008. «Process simulation of natural gas steam reforming: Fuel distribution optimisation in the furnace». Fuel Process. Technol., 89 (6), 622-632.

[57] BARNETT, D. eta WU, D. 2000. «Flue-gas circulation and heat distribution in reformer furnaces». 45th Annual Safety in Ammonia Plants and Related Facilities Symposium, Tucson (AEB), 9-16.

[58] STEFANIDIS, G.D., MERCI, B., HEYNDERICKX, G.J. eta MARIN, G.B. 2006. «CFD simulations of steam cracking furnaces using detailed combustion mechanisms». Comput. Chem. Eng., 30 (4), 635-649.

[59] FAMELL, P.W. eta COTTON, W.J. 1999. «Flue-gas flow patterns in top-fired steam reforming furnaces». 44th Annual Safety in Ammonia Plants and Related Facilities Symposium, Seattle (AEB), 144-158.

[60] DARVISHI P. eta ZAREIE-KORDSHOULI, F. 2017. «A rigorous mathematical model for online prediction of tube skin temperature in an industrial top-fired steam methane reformer». Chem. Eng. Res. Des., 126, 32-44.

[61] TRAN, A.T. 2018. Computational fluid dynamics and machine learning modeling, operation and control of steam methane reforming reactors and furnaces. M.Sc.E. Thesis, University of California, Los Angeles.

[62] ZAMANIYAN, A., JODA, F., BEHROOZSARAND, A. eta EBRAHIMI, H. 2013. «Application of artificial neural networks (ANN) for modeling of industrial hydrogen plant». Int. J. Hydrog. Energy, 38, 6289-6297. 
